\title{
Iatrogenic tattoos after acupuncture: successful outcome after treatment with QS Ruby Laser: A case report and review of literature
}

\author{
Corinne DC Eggenschwiler ${ }^{1,2}$, Reinhard Dummer MD ${ }^{1,2}$, Laurence Imhof MD ${ }^{1,2}$ \\ 1: Department of Dermatology, University Hospital of Zurich, Gloriastrasse 31, 8091 Zurich, Switzerland \\ 2: Faculty of Medicine, University of Zurich, Pestalozzisrasse 3, 8091 Zurich, Switzerland
}

\begin{abstract}
Background and Aims: Acupuncture has become a substantial part of medical practice in Switzerland. So far, only few cases of accidental tattoo after acupuncture have been reported, which were all caused by acupuncture needles that had been left in the skin and led to local argyrosis.

Case: We report the case of a 31-year-old female who developed gray-brown macules after acupuncture. Over 5 months, she had received acupuncture on the same spots one to two times per week and the macules had gradually become darker and had increased in size. The needles used were disposable, contained nickel and were not left in the skin for over 30 minutes. The patient was of Fitzpatrick skin phototype II and showed several grayish-brown macules with an average diameter of around $5 \mathrm{~mm}$ in the region of glabella, nucha and dorsum pedis. We treated the lesions with a quality-switched ruby laser (694 $\mathrm{nm}$ ) with a fluence between 3 and $5.5 \mathrm{~J} / \mathrm{cm}^{2}$, a spot size of 4 or $6 \mathrm{~mm}$ and in intervals of 8 to 23 weeks up to a complete elimination of the hyperpigmentation within 11 laser sessions.

Conclusion: In synopsis with the anamnesis, the clinical aspect and the therapeutic course, we interpreted the hyperpigmentary spots as a combination of iatrogenic tattooing with nickel and deposition of hemosiderin as well as melanin due to repeated mechanical manipulation and UV exposure of the skin. Furthermore, we hereby show the validity of the quality-switched ruby laser in the removal of accidental hyperpigmentation in skin phototype II.
\end{abstract}

Key words: Laser Therapy $\cdot$ QS Ruby Laser $\cdot$ Accidental Tattoo $\cdot$ Iatrogenic tattoo Accidental Hyperpigmentation • Acupuncture

\section{Introduction}

Acupuncture as a part of complementary medicine has become a substantial part of medical practice in Switzerland. ${ }^{1,2)}$ Indications range from postoperative discomfort and pain to addiction disorders. The principle can be explained by a stimulating effect on the organism upon needle insertion into the skin. Thus, dysregulations of different origins are supposed to be corrected or ameliorated, respectively. The exact mechanism of the therapeutic effect of acupuncture needling is not yet fully understood and difficult to prove as placebo controls in randomized

Addressee for Correspondence:

Eggenschwiler Corinne D.C.

Doktorandin

Department of Dermatology, University Hospital of Zurich/

Faculty of Medicine, University of Zurich Gloriastrasse 318091

Zürich

corinne.eggenschwiler@usz.ch

Tel: +414425525 59 controlled studies are not simple to implement. ${ }^{3)}$

Accidental tattoos are defined as a permanent deposition of exogenous pigment in the dermis and/or subcutis after a skin injury. Causes include abrasive or explosive trauma as well as iatrogenic measures such as chronic drug intake and sutures or metallic objects permanently left in the skin. ${ }^{4,5,6,7)}$ Once a traumatic tattoo has developed, the most efficient and safest way to remove it is by laser therapy. 8,9,10,12,13) Alternative therapies such as dermabrasion or excision are accompanied by a significant risk for further scarring. ${ }^{4,14)}$ Laser therapy on the contrary is rarely associated with long-term complications and supported well by the patients. A disadvantage is the longer duration of the treatment as often, several laser sessions are required to lead to a satisfactory result. $8,9,10,12,13)$

Received date: March 26th, 2019

Accepted date: April 16th, 2019 
Very few papers on accidental tattoos after acupuncture have been published. ${ }^{15,16,17)}$ They all present cases of acupuncture needles being left in the skin for therapeutic reasons with subsequent argyrosis due to the silver pigment particles that the needles contained. After thorough research on adverse events however, no case of accidental or postinflammatory hyperpigmentation after acupuncture with nickel containing needles was found. To our knowledge, this is the first case report on accidental hyperpigmentation after acupuncture with nickel needles. Furthermore, we show the therapeutic success of a quality-switched (QS) ruby laser to remove accidental tattoos in a fair skin phototype.

\section{Case Description}

A 31-year-old female presented due to grayish-brown macules that had occurred after acupuncture. The lesions had developed 1.5 years ago and had started to bother the patient as they turned more visible half a year later. Over 5 months, she had received acupuncture on the same spots one to two times per week and the macules had gradually become darker and had increased in size. The needles used were disposable, contained nickel and were not left in the skin for over 30 minutes. No herbal supplements and no heating of the needles were used.

The patient was of Fitzpatrick skin phototype II and showed several grayish-brown macules of around $5 \mathrm{~mm}$ in the region of glabella, nucha and dorsum pedis on both sides (Fig. 1-3). Before the consultation, she had tried ointments to lighten up the lesions, but with no success. Previously, the patient had undergone treatment by acupuncture several times in the past years and had never experienced a similar side effect.

We treated the lesions with a QS ruby laser (694 nm wavelength). A fluence between 3 and $5.5 \mathrm{~J} / \mathrm{cm}^{2}$, a spot size between 4 and $6 \mathrm{~mm}$ and a frequency of $1.5 \mathrm{~Hz}$ was used. A larger spot size required a lower fluence. The laser sessions were performed in intervals of 8 to 23 weeks and depending on the degree of hyperpigmentations, a total of 11 laser treatments were carried out. The gradual lightening of the macules was monitored by regular photodocumentation and showed excellent results with a complete removal of the hyperpigmented regions. Our patient was very satisfied with the results and supported the treatment well without any mentionable side effects or complications except for some slight hyperpigmentations on the neck, which were removed in a single session with a QS Nd:YAG laser.

Written informed consent for the use of clinical photography was obtained.

\section{Discussion}

Complimentary medicine, which has become consider- ably significant for the Swiss population, includes acupuncture. ${ }^{1,2)}$ If practiced by an approved physician, it is covered by the Swiss health insurance. According to the data of the Swiss Health Surveys from the year 2007 and 2012, 4.9\% of the Swiss population used acupuncture within a period of 12 months. ${ }^{2)}$ Acupuncture can be performed in various methods. ${ }^{18)}$ The needles can be bluntly inserted in the skin, enriched with herbal additives, bee venom or be permanently left in the skin for enhanced effect. ${ }^{19)}$ Regarding the method of needle insertion such as the depth of penetration, there are differences in the Japanese, Korean and Chinese approaches. ${ }^{20)}$

In reviews concerning adverse events after acupuncture, a case comparable to ours has not yet been published. An extensive Japanese prospective multicenter study ${ }^{20)}$ analyzed the data of 2180 acupuncture-patients and reported adverse events in $6.03 \%$ of patients. Most of these were mild local bleeding and hematoma, discomfort and pain at insertion site. Park et al ${ }^{19)}$ observed 25 patients and described cutaneous infections and local reactions associated with hypersensitivity as the main dermatological adverse events. Xu et al ${ }^{21)}$ confirmed local infections as the most common side effect. A systematic review ${ }^{22}$ carried out in China in 2015 states that organ or tissue injuries are the most frequent adverse events, followed by infections, local reactions and general symptoms such as nausea. This review is one of two publications that describe local argyrosis as a result of acupuncture with permanently embedded silver needles. 17) Another Chinese systematic review additionally names pneumothorax, central and peripheral nerve lesions. ${ }^{23)}$ Shin et al ${ }^{24)}$ listed pruritus, hemorrhage, bruises and palsy as most common side effects occurred in 3.7\% of Korean acupuncture patients. A prospective observational study 25) on 229' 230 German acupuncture-patients observed at least one adverse event in $8.6 \%$ of them. In most cases, it was bleeding, hematoma or local pain.

Summarizing the publications analyzed, we can say that acupuncture is a relatively safe treatment with rarely occurring, mostly mild and temporary side effects. To date, persistent hyperpigmentation after acupuncture is not a well-known complication.

Our case shows similarities to a report from Kazlouskaya et al. ${ }^{26}$ ) The latter describes a patient with focal gray-blue hyperpigmentation after repeated heroin injection. A biopsy of the hyperpigmented area showed dermal intracellular granules containing melanin and iron particles. The origin of the accidental tattoo was attributed to either contaminating components in the injected drug or to carbon, which is released during disinfection of the needles with fire. Additionally, erythrocyte leakage and postinflammatory hyperpigmentation might have contributed. The lesions were successfully removed within five QS Nd:YAG 1064nm laser sessions.

In our case, there are several possible causes for the 

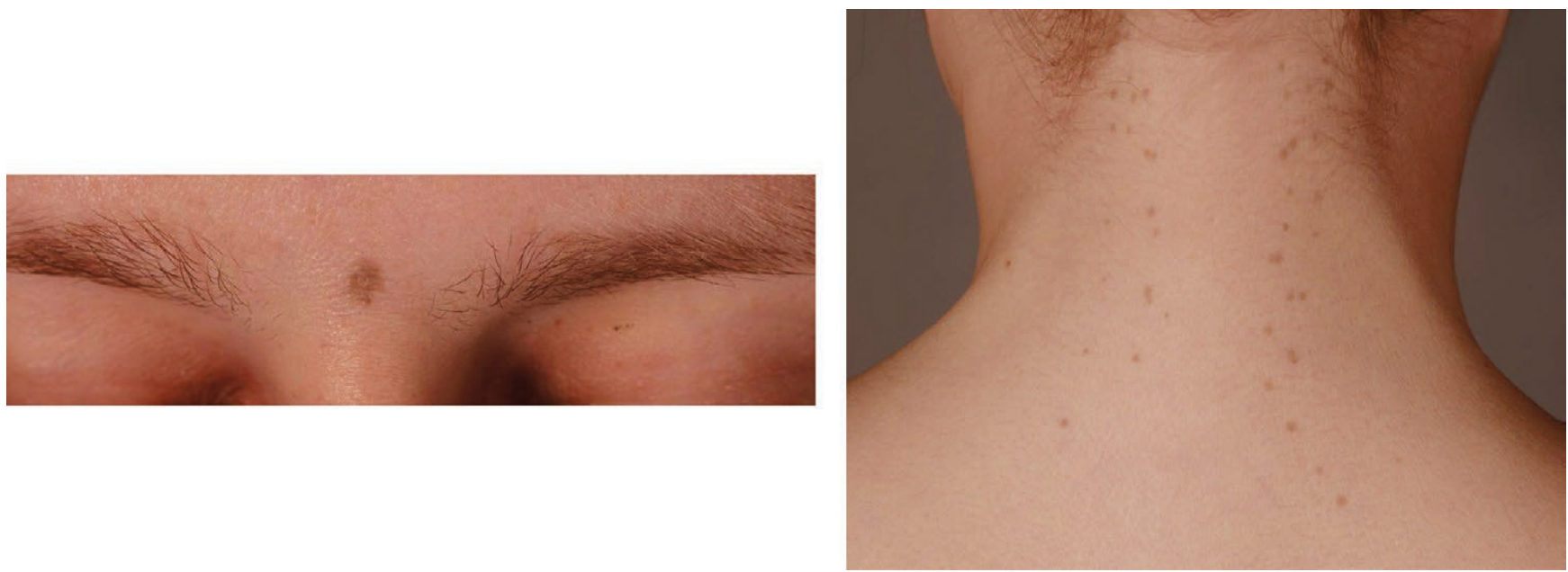

Figure 1: Hyperpigmentation before start of laser therapy
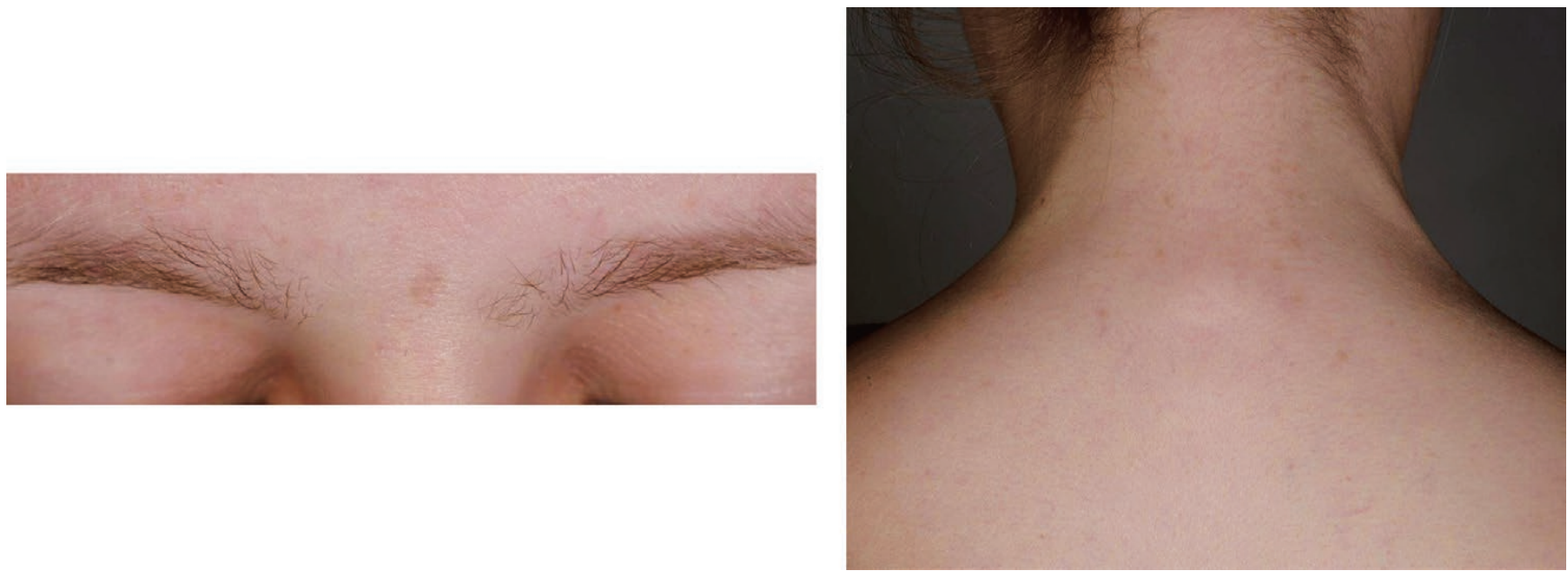

Figure 2: Remaining hyperpigmentation after three laser sessions with the QS ruby laser
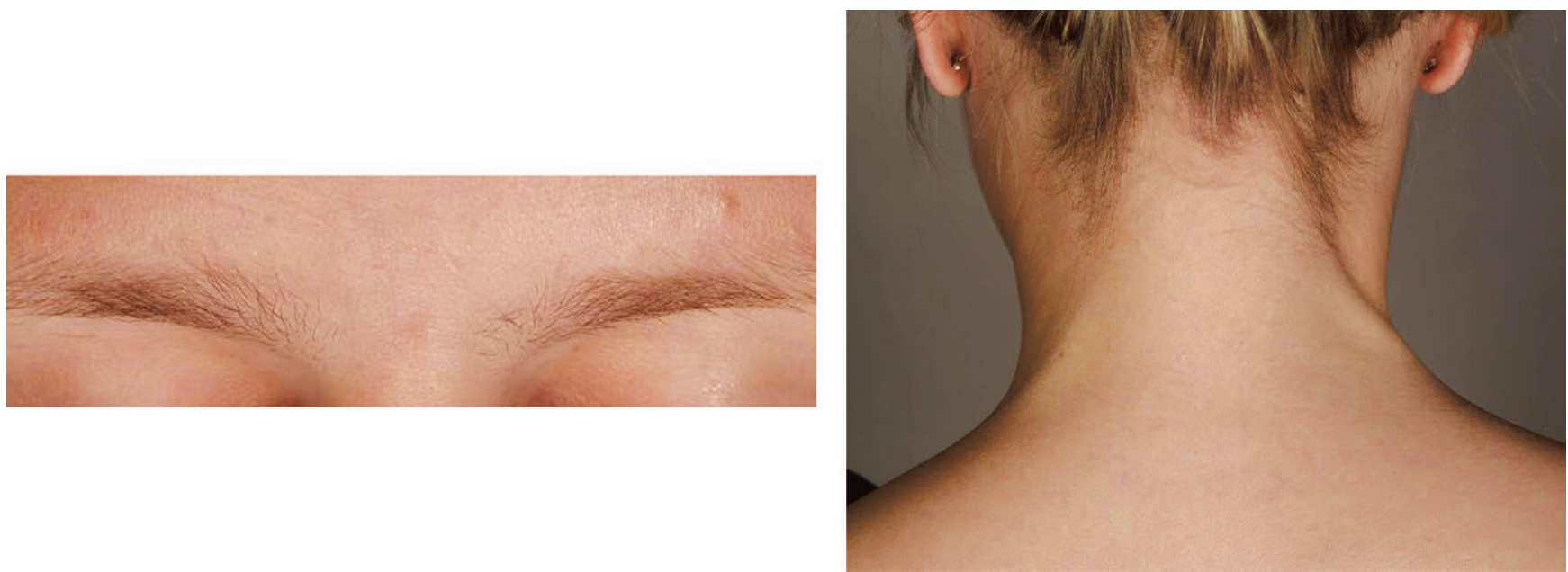

Figure 3: Complete removal of the hyperpigmentation after 11 laser sessions 
hyperpigmentation after acupuncture:

1. A permanent deposition of exogenous pigment in the dermis is possible. Two case reports ${ }^{15,16)}$ and one Japanese review ${ }^{17)}$ describe localized hyperpigmentation after acupuncture due to deposits of exogenous pigment (Table 1). All cases were associated with localized argyria after acupuncture with silver needles left in the skin. As in our case the needles were removed within 30 minutes and disposable nickel needles were used, argyrosis does not seem probable. Moreover, local argyrosis usually has a rather blue-gray aspect on contrary to the grayish-brown macules in our case. What needs to be taken into consideration in our case is a nickel deposit in the treated skin that led to the accidental tattoos. To date, there is no corresponding case in the literature in which nickel leads to permanent discoloration of the skin.

2. A further potential cause is a contamination of the needles with carbon or graphite, brought into the dermis during acupuncture. Lack of hygiene is often named as a main factor for the occurrence of complications after therapy. ${ }^{19,20,21,22)}$ Unfortunately, it was impossible for us to examine the circumstances under which acupuncture was carried out on our patient. However, as the treatment sessions took place in an approved practice in Switzerland, we assume that hygiene standards were adequate and that a contamination of the acupuncture needles is rather improbable. Moreover, our patient denied that the needles were heated before their insertion, which could have brought substances such as carbon into the skin.

3. Irritation or inflammatory reaction of the skin can lead to postinflammatory hyperpigmentation (PIH). Repeated local manipulation with the needles may have caused increased melanin production. PIH tends to occur most commonly in inviduals with Fitzpatrick skin phototypes III or more. ${ }^{27,28)}$ Our patient with a skin phototype II is therefore not the typical candidate for it. Moreover, the number of laser sessions (up to 11) required to eliminate the hyperpigmentation is not in favour of a PIH as it is generally removed within far less sessions. In our experience, a QS ruby laser can successfully remove PIH within one to two sessions. ${ }^{29)}$ This argument is further fortified by the fact that our patient developed a mild PIH after laser therapy in the course of the treatment, which was easily removed within one session with a QS Nd:YAG $532 \mathrm{~nm}$ laser. Hence, the primary hyperpigmented macules must have differed from the latter.

4. Solar exposure promotes the development of PIH,

Table 1: Publications on local argyrosis after acupuncture $(n=3)$

\begin{tabular}{|c|c|c|c|c|c|c|c|c|}
\hline Authors & $\begin{array}{c}\text { Year of } \\
\text { Publication } \\
\end{array}$ & Journal & Pathology & $\begin{array}{l}\text { Clinical } \\
\text { Aspect }\end{array}$ & Histology & Material & Cause & Treatment \\
\hline $\begin{array}{l}\text { Kakurai } \\
\text { et al }\end{array}$ & 2002 & $\begin{array}{l}\text { British Jour- } \\
\text { nal of Derma- } \\
\text { tology }\end{array}$ & $\begin{array}{l}1 \text { case of } \\
\text { localized } \\
\text { argyria }\end{array}$ & $\begin{array}{c}\text { multiple } \\
\text { blue-black } \\
\text { macules and } \\
\text { nodules }\end{array}$ & $\begin{array}{l}\text { brown } \\
\text { pigment in } \\
\text { dermis } \\
\text { surrounded } \\
\text { by mast } \\
\text { cells, foreign } \\
\text { body } \\
\text { reaction }\end{array}$ & $\begin{array}{c}\text { silver, } \\
\text { selenium } \\
\text { and sulphur }\end{array}$ & $\begin{array}{l}\text { acupuncture } \\
\text { needles left } \\
\text { in the skin }\end{array}$ & $\begin{array}{l}\text { none } \\
\text { reported }\end{array}$ \\
\hline $\begin{array}{l}\text { Tanita } \\
\text { et al }\end{array}$ & 1985 & $\begin{array}{l}\text { Arch Derma- } \\
\text { tology }\end{array}$ & $\begin{array}{l}1 \text { case of } \\
\text { localized } \\
\text { argyria }\end{array}$ & $\begin{array}{c}\text { multiple } \\
\text { blue macules }\end{array}$ & $\begin{array}{l}\text { black } \\
\text { granules in } \\
\text { dermis } \\
\text { around } \\
\text { vascular, } \\
\text { fiber and } \\
\text { gland } \\
\text { structures }\end{array}$ & $\begin{array}{c}\text { silver, } \\
\text { chloride and } \\
\text { mercury }\end{array}$ & $\begin{array}{l}\text { acupuncture } \\
\text { needles left } \\
\text { in the skin }\end{array}$ & $\begin{array}{l}\text { excision } \\
\text { of the } \\
\text { needles }\end{array}$ \\
\hline $\begin{array}{l}\text { Yamashita } \\
\text { et al }\end{array}$ & 2001 & $\begin{array}{l}\text { Complementary } \\
\text { Therapies in } \\
\text { Medicine }\end{array}$ & $\begin{array}{l}10 \text { cases of } \\
\text { localized } \\
\text { argyria and } \\
1 \text { case of } \\
\text { cutaneous } \\
\text { chromatosis }\end{array}$ & $\begin{array}{l}\text { none } \\
\text { reported }\end{array}$ & $\begin{array}{l}\text { none } \\
\text { reported }\end{array}$ & silver & $\begin{array}{l}\text { none } \\
\text { reported }\end{array}$ & $\begin{array}{l}\text { none } \\
\text { reported }\end{array}$ \\
\hline
\end{tabular}


especially in darker skin. ${ }^{27,}{ }^{28)}$ Our patient admitted to regularly exposing herself to UV. Thus, UV-aggravated PIH must be taken into consideration.

5. A further explanation is erythrocyte leakage due to the repeated mechanical manipulation. The permanent deposition of hemosiderin in tissue that can be associated with discoloration.

Unfortunately, the patient did not agree to undergo a skin biopsy for verification of exogenous particles in the dermis. We can therefore not definitely elicit the origin of the accidental tattoo. We cannot rule out that the practitioner did not use the needles he had claimed or that he had added a substance that was not communicated to the patient. We do however base our interpretations on the statements of the patient and on our clinical observations.

In synopsis with the anamnesis, the clinical aspect and the therapeutic course, we interpreted the hyperpigmentary spots as a combination of iatrogenic tattooing with nickel and deposits with hemosiderin as well as melanin due to repeated mechanical manipulation and UV exposure on the skin.

\section{References}

1: Wolf U, Maxion-Bergemann S, Bornhöft G, Matthiessen P and Wolf M. "Use of Complementary Medicine in Switzerland". Complementary Medicine Research 13 (suppl 2), Nr. s02 (2006): 4-6.

2: Klein SD, Loredana Torchetti L, Frei-Erb M and Wolf U. "Usage of Complementary Medicine in Switzerland: Results of the Swiss Health Survey 2012 and Development Since 2007". Herausgegeben von Robert M Lafrenie. PLoS ONE 10, Nr. 10 (2015): e0141985. doi:10.1371/journal.pone.0141985.

3: Acupuncture. NIH Consensus Statement Online 1997 Nov 3-5; month, day]; 15(5):1-34.

4: Kent KM and Graber EM. "Laser Tattoo Removal: A Review". Dermatologic Surgery 38, Nr. 1 (2. November 2011): 1-13. doi:10.1111/j.1524-4725.2011.02187.x.

5: Singer AJ and Dagum AB. "Current Management of Acute Cutaneous Wounds". New England Journal of Medicine 359, Nr. 10 (4. September 2008): 1037-46. doi:10.1056/NEJMra0707253.

6: Bernstein LJ, Palaia DA, Bank D and Geronemus RG. "Tattoo Formation from Absorbable Synthetic Suture and Successful Removal with Q-Switched Ruby Laser". Dermatologic Surgery 22, Nr. 12 (1996).

7: Dereure O. "Drug-Induced Skin Pigmentation: Epidemiology, Diagnosis and Treatment". American journal of clinical dermatology 2 (2001): 253-62.

8: Imhof L, Dummer R. Iatrogene Tätowierung nach Eiseninfusion. Swiss Med Forum 2014;14:750-1

9: Haywood, RM, Monk BE and Mahaffey PJ. "Treatment of traumatic tattoos with the Nd YAG laser: a series of nine cases". British Journal of Plastic Surgery 52, Nr. 2 (1. März 1999): 97-98. doi:10.1054/bjps.1998.3054.

10: Seitz AT, Grunewald S, Wagner JA, Simon JC and Paasch U. "Fractional $\mathrm{CO}_{2}$ laser is as effective as Q-switched ruby laser for the initial treatment of a traumatic tattoo". Journal of Cosmetic and Laser Therapy 16, Nr. 6 (1. Dezember 2014): 303-5. doi:10.3109/14764172.2014.956669.

11: Miles BA and Ellis E. "The Neodymium:YAG Laser in the Treatment of Traumatic Tattoo: A Case Report". Journal of Oral and Maxillofacial Surgery 64, Nr. 5 (1. Mai 2006): 85055. doi:10.1016/j.joms.2006.01.015.

12.: Martins A, Trindade F and Leite L. "Facial scars after a road accident - combined treatment with pulsed dye laser and Q-switched Nd:YAG laser". Journal of Cosmetic Dermatology 7, Nr. 3 (5. August 2008): 227-29. doi:10.1111/j.1473-2165. 2008.00394.x

13: Troilius AM. "Effective treatment of traumatic tattoos with a Q-switched Nd:YAG laser". Lasers in Surgery and Medicine 22, Nr. 2 (7. Dezember 1998): 103-8. doi:10.1002/(SICI)1096-
9101(1998)22:2<103::AID-LSM6>3.0.CO;2-T.

14: Sweeney SM. "Tattoos: a review of tattoo practices and potential treatment options for removal". Current Opinion in Pediatrics 18, Nr. 4 (2006).

15: Tanita Y, Kato T, Hanada K and Tagami H. "Blue macules of localized argyria caused by implanted acupuncture needles: Electron microscopy and roentgenographic microanalysis of deposited metal". Archives of Dermatology 121, Nr. 12 (1. Dezember 1985): 1550-52. doi:10.1001/archderm. 1985.01660120076024.

16: Kakurai, M, Demitsu T, Umemoto N, Ohtsuki M and Nakagawa $\mathrm{H}$. "Activation of mast cells by silver particles in a patient with localized argyria due to implantation of acupuncture needles". British Journal of Dermatology 148, Nr. 4 (2003): 822-822. doi:10.1046/j.1365-2133.2003.05188.x.

17: Yamashita, H, Tsukayama H, White AR, Tanno Y, Sugishita C et al. "Systematic review of adverse events following acupuncture: the Japanese literature". Complementary Therapies in Medicine 9, Nr. 2 (1. Juni 2001): 98-104. doi:10.1054/ ctim.2001.0446.

18: World Health Organisation. "WHO international standard terminologies on traditional medicine in the Western Pacific region". Manila, Philippines (2007).

19: Park SM, Kim WJ, Mun JH, Kim HS, Ko HC et al. "Adverse events associated with acupuncture: a clinicopathologic review". International Journal of Dermatology 55, Nr. 7 (2016) 757-63. doi:10.1111/ijd.12914.

20: Furuse N, Shinbara H, Uehara A, Sugawara M, Yamazaki T et al. "A Multicenter Prospective Survey of Adverse Events Associated with Acupuncture and Moxibustion in Japan". Medical Acupuncture 29, Nr. 3 (1. Juni 2017): 155-62. doi:10.1089/acu.2017.1230

21: Xu S, Wang L, Cooper E, Zhang M, Manheimer E et al. "Adverse Events of Acupuncture: A Systematic Review of Case Reports". Evidence-based Complementary and Alternative Medicine : eCAM 2013 (2013): 581203 . doi:10.1155/2013/581203.

22: Chan MWC, Wu XY, Wu JCY, Wong SYS and Chung VCH. "Safety of Acupuncture: Overview of Systematic Reviews". Scientific Reports 7 (2017): 3369. doi:10.1038/s41598-01703272-0.

23 Wu J, Hu Y, Zhu Y, Yin P, Litscher G et al. "Systematic Review of Adverse Effects: A Further Step towards Modernization of Acupuncture in China". Evidence-based Complementary and Alternative Medicine: eCAM 2015 (2015): 432467. doi: $10.1155 / 2015 / 432467$.

24 Shin HK, Jeong SJ, Huang DS, Kang BK and Lee MS. "Usage patterns and adverse experiences in traditional Korean med- 
icine: results of a survey in South Korea". BMC Complementary and Alternative Medicine 13 (2013): 340-340. doi:10.1186/1472-6882-13-340.

25 Witt CM, Pach D, Brinkhaus B, Wruck K, Tag B et al. "Safety of Acupuncture: Results of a Prospective Observational Study with 229,230 Patients and Introduction of a Medical Information and Consent Form". Complementary Medicine Research 16, Nr. 2 (2009): 91-97

26 Kazlouskaya V, Sagerman PM, Goldberg GN and Gottesman SP. "A case of heroin linear track hyperpigmentation: histopathology and treatment with Q-switched Nd:YAG 1064nm laser". International Journal of Dermatology, o. J., n/a-n/a. doi:10.1111/ijd.13861.

27 Silpa-archa N, Kohli I, Chaowattanapanit S, Lim HW and
Hamzavi I. "Postinflammatory hyperpigmentation: A comprehensive overview: Epidemiology, pathogenesis, clinical presentation, and noninvasive assessment technique". Journal of the American Academy of Dermatology 77, Nr. 4 (1. Oktober 2017): 591-605. doi:10.1016/j.jaad.2017.01.035.

28 Halder RM and Nootheti PK. "Ethnic skin disorders overview". Journal of the American Academy of Dermatology 48, Nr. 6, Supplement (1. Juni 2003): S143-48. doi:10.1067/ mjd.2003.274.

29 haowattanapanit S, Silpa-archa N, Kohli I, Lim HW and Hamzavi I. "Postinflammatory hyperpigmentation: A comprehensive overview: Treatment options and prevention". Journal of the American Academy of Dermatology 77, Nr. 4 (1. Oktober 2017): 607-21. doi:10.1016/j.jaad.2017.01.036.

\section{Acknowledgments}

The authors declare no conflicts of interest. 